\title{
Pterocarpadiols A-D, Rare 6a,11b-Dihydroxypterocarpans from Derris robusta
}

\author{
Xiang-Mei Li $\cdot$ Mei-Fen Mao $\cdot$ Fu-Cai Ren $•$ \\ Xian-Jun Jiang $\cdot$ Ping Hai $\cdot$ Fei Wang
}

Received: 19 October 2015/ Accepted: 25 October 2015/Published online: 7 November 2015

(C) The Author(s) 2015. This article is published with open access at Springerlink.com

\begin{abstract}
Four hitherto unknown 6a,11b-dihydroxypterocarpans, namely pterocarpadiols A-D (1-4), were isolated from the ethanol extract of the twigs and leaves of Derris robusta. Their structures were elucidated on the basis of extensive spectroscopic analysis. Pterocarpadiols A-D are a kind of very rare 6a,11b-dihydroxypterocarpans, and their presence as markers may be helpful in chemotaxonomical classification.
\end{abstract}

\section{Graphical Abstract}

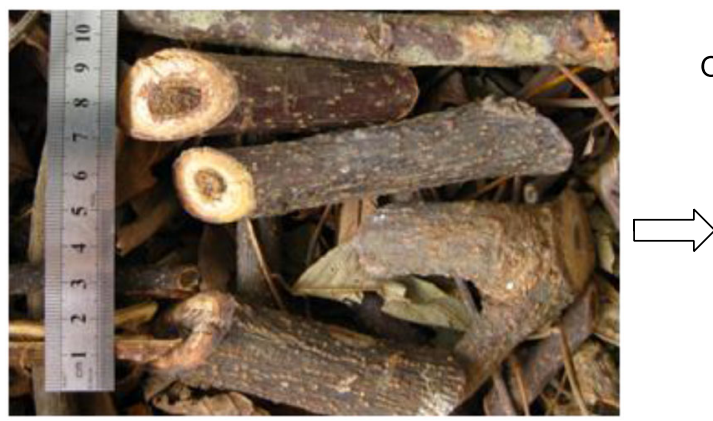<smiles>[R2]c1cc2c(cc1[R2])[C@@]1(O)COC3=CC(=O)C=C[C@]3(O)[C@H]1O2</smiles>

$1 \mathrm{R}_{1}, \mathrm{R}_{2}=\mathrm{OCH}_{2} \mathrm{O}$

$2 \mathrm{R}_{1}=\mathrm{H}, \mathrm{R}_{2}=\mathrm{OCH}_{3}$<smiles>[R]c1cc2c(cc1[R])[C@]1(O)COC3=CC(=O)CC[C@]3(O)[C@H]1O2</smiles>

$3 \mathrm{R}_{1}, \mathrm{R}_{2}=\mathrm{OCH}_{2} \mathrm{O}$

$4 \mathrm{R}_{1}=\mathrm{H}, \mathrm{R}_{2}=\mathrm{OCH}_{3}$

Derris robusta

Keywords Derris robusta $\cdot$ 6a,11b-Dihydroxypterocarpan · Pterocarpadiol

Electronic supplementary material The online version of this article (doi:10.1007/s13659-015-0078-y) contains supplementary material, which is available to authorized users.

X.-M. Li · M.-F. Mao · F.-C. Ren · X.-J. Jiang · P. Hai ·

F. Wang $(\bowtie)$

BioBioPha Co., Ltd., Kunming 650201,

People's Republic of China

e-mail: f.wang@mail.biobiopha.com

\section{Introduction}

The genus Derris (Leguminosae) contains about 800 species, widely distributed in tropical and subtropical parts of the world [1]. The bark and leaves of Derris species are commonly utilized as folk medicine to treat human diseases such as arthritis and eczema [2]. The extracts and reported chemical constituents exhibit antioxidant, antibacterial and pesticidal activities [2]. Previous studies show the genus is a rich source of flavonoids, isoflavonoids, pterocarpans and rotenoids [2]. As part of a 
BioBioPha [http://www.chemlib.cn] objective to assemble a large-scale natural product library very valuable in the discovery of new drug leads from nature [3-7], the phytochemical investigation on the twigs and leaves of Derris robusta led to the isolation of four new $6 \mathrm{a}, 11 \mathrm{~b}$-dihydroxypterocarpans, namely pterocarpadiols A-D (1-4), together with 10 known pterocarpans: 1,11b-dihydro-11b-hydroxymaackiain (5) [8], 1,11b-dihydro-11b-hydroxymedicarpin (6) [8], pisatin (7) [9], variabilin (8) [10], 6a-hydroxymaackiain (9) [11], 6a-hydroxymedicarpin (10) [12], maackiain (11) [13], medicarpin (12) [14], 3-hydroxy-8,9-methylenedioxypterocarpene (13) [15], and anhydroglycinol (14) [16].

Table $1{ }^{1} \mathrm{H}$ NMR spectroscopic data for pterocarpadiols A-D (1-4) in $\mathrm{CD}_{3} \mathrm{OD}\left(\delta_{\mathrm{H}} 3.30 \mathrm{ppm}\right)$

\begin{tabular}{lllll}
\hline No. & $\mathbf{1}$ & $\mathbf{2}$ & $\mathbf{3}$ & $\mathbf{4}$ \\
\hline 1 & $6.80(\mathrm{~d}, 10.0)$ & $6.83(\mathrm{~d}, 10.0)$ & $2.64(\mathrm{td}, 13.9,4.5, \mathrm{H} \beta)$ & $2.68(\mathrm{td}, 13.9,4.0, \mathrm{H} \beta)$ \\
& & $2.01(\mathrm{ddd}, 13.9,4.5,2.5, \mathrm{H} \alpha)$ & $2.03(\mathrm{ddd}, 13.9,5.0,2.0, \mathrm{H} \alpha)$ \\
2 & $6.09(\mathrm{dd}, 10.0,1.8)$ & $6.10(\mathrm{dd}, 10.0,1.8)$ & $2.76(\mathrm{ddd}, 16.5,13.9,4.5, \mathrm{H} \alpha)$ & $2.77(\mathrm{ddd}, 16.2,13.9,5.0, \mathrm{H} \alpha)$ \\
& & $2.31(\mathrm{ddd}, 16.5,4.5,2.5, \mathrm{H} \beta)$ & $5.34(\mathrm{ddd})$ \\
4 & $5.41(\mathrm{~d}, 1.8)$ & $5.39(\mathrm{~d}, 1.8)$ & $5.35(\mathrm{~s})$ & $4.68(\mathrm{~d}, 10.0, \mathrm{H} \alpha)$ \\
6 & $4.99(\mathrm{~d}, 10.5, \mathrm{H} \alpha)$ & $5.02(\mathrm{~d}, 10.6, \mathrm{H} \alpha)$ & $4.65(\mathrm{~d}, 10.0, \mathrm{H} \alpha)$ & $4.32(\mathrm{~d}, 10.0, \mathrm{H} \beta)$ \\
7 & $4.37(\mathrm{~d}, 10.5, \mathrm{H} \beta)$ & $4.39(\mathrm{~d}, 10.6, \mathrm{H} \beta)$ & $4.30(\mathrm{~d}, 10.0, \mathrm{H} \beta)$ & $7.25(\mathrm{~d}, 8.0)$ \\
8 & $6.81(\mathrm{~s})$ & $7.25(\mathrm{~d}, 8.5)$ & $6.81(\mathrm{~s})$ & $6.56(\mathrm{dd}, 8.0,2.0)$ \\
10 & $6.55(\mathrm{dd}, 8.5,2.4)$ & & $6.36(\mathrm{~d}, 2.0)$ \\
$11 \mathrm{a}$ & $6.26(\mathrm{~s})$ & $6.29(\mathrm{~d}, 2.4)$ & $6.34(\mathrm{~s})$ & $4.51(\mathrm{~s})$ \\
$\mathrm{OCH}_{2} \mathrm{O}$ & $5.90(\mathrm{~d}, 1.0)$ & $4.75(\mathrm{~s})$ & $4.48(\mathrm{~s})$ & $5.91(\mathrm{~s})$ \\
$\mathrm{OCH}_{3}$ & $5.89(\mathrm{~d}, 1.0)$ & & $5.89(\mathrm{~s})$ & $3.74(\mathrm{~s})$ \\
\hline
\end{tabular}

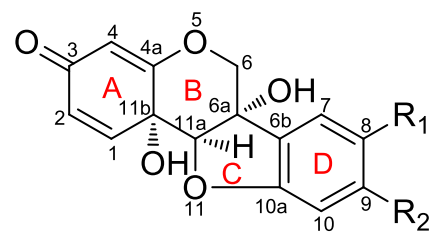

$1 \mathrm{R}_{1}, \mathrm{R}_{2}=\mathrm{OCH}_{2} \mathrm{O}$

$2 \mathrm{R}_{1}=\mathrm{H}, \mathrm{R}_{2}=\mathrm{OCH}_{3}$<smiles>[R2]c1cc2c(cc1[R2])[C@@]1(O)COc3cc(OC)ccc3[C@@]1([2H])O2</smiles>

$7 \mathrm{R}_{1}, \mathrm{R}_{2}=\mathrm{OCH}_{2} \mathrm{O}$

$8 \mathrm{R}_{1}=\mathrm{H}, \mathrm{R}_{2}=\mathrm{OCH}_{3}$<smiles>[R2]c1cc2oc3c(c2cc1[R2])COc1cc(O)ccc1-3</smiles>

$13 \mathrm{R}_{1}, \mathrm{R}_{2}=\mathrm{OCH}_{2} \mathrm{O}$

$14 \mathrm{R}_{1}=\mathrm{H}, \mathrm{R}_{2}=\mathrm{OH}$<smiles>[R2]c1cc2c(cc1[R2])[C@@]1(O)COC3=CC(=O)CC[C@]3(O)[C@H]1O2</smiles>

$3 \mathrm{R}_{1}, \mathrm{R}_{2}=\mathrm{OCH}_{2} \mathrm{O}$

$4 \mathrm{R}_{1}=\mathrm{H}, \mathrm{R}_{2}=\mathrm{OCH}_{3}$

$\mathrm{HO}$<smiles>[R2]c1cc2c(cc1[R2])[C@@]1(O)COc3cc(C)ccc3[C@H]1O2</smiles>

$9 \mathrm{R}_{1}, \mathrm{R}_{2}=\mathrm{OCH}_{2} \mathrm{O}$

$10 \mathrm{R}_{1}=\mathrm{H}, \mathrm{R}_{2}=\mathrm{OCH}_{3}$

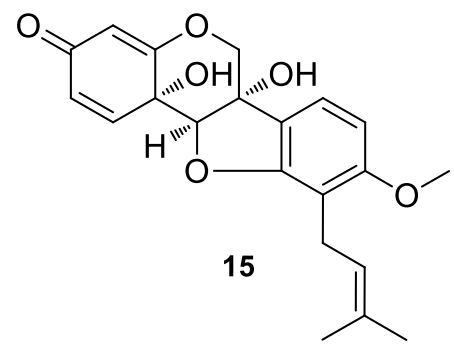<smiles>[R2]c1cc2c(cc1[R2])[C@@H]1COC3=CC(=O)CC[C@]3(O)[C@H]1O2</smiles>

$5 \mathrm{R}_{1}, \mathrm{R}_{2}=\mathrm{OCH}_{2} \mathrm{O}$

$6 \mathrm{R}_{1}=\mathrm{H}, \mathrm{R}_{2}=\mathrm{OCH}_{3}$<smiles>[R2]c1cc2c(cc1[R2])[C@@]1([2H])COc3cc(O)ccc3[C@H]1O2</smiles>

$11 \mathrm{R}_{1}, \mathrm{R}_{2}=\mathrm{OCH}_{2} \mathrm{O}$

$12 \mathrm{R}_{1}=\mathrm{H}, \mathrm{R}_{2}=\mathrm{OCH}_{3}$

Fig. 1 Pterocarpans from Derris robusta (1-14) and hydroxycristacarpone (15) 
Among the known pterocarpans, compounds 5-10 and 14 were isolated from the genus for the first time. This paper reports the isolation and structure elucidation of pterocarpadiols A-D.

\section{Results and Discussion}

Compound 1, obtained as amorphous powder, had a molecular formula of $\mathrm{C}_{16} \mathrm{H}_{12} \mathrm{O}_{7}$ as deduced from its positive-ion HRESIMS at $\mathrm{m} / z$ 339.0462 $[\mathrm{M}+\mathrm{Na}]^{+}$(calcd for $\mathrm{C}_{16} \mathrm{H}_{12} \mathrm{O}_{7} \mathrm{Na}$, 339.0475), requiring 11 degrees of unsaturation. The ${ }^{1} \mathrm{H}$ NMR spectrum (Table 1) showed three characteristic aliphatic protons of 6a-hydroxypterocarpan skeleton at $\delta_{\mathrm{H}} 4.99,4.37$ (each $\left.1 \mathrm{H}, \mathrm{d}, J=10.5 \mathrm{~Hz}, \mathrm{H}-6\right)$, and 4.73 (s, H-11a) [17]. The ${ }^{13} \mathrm{C}$ NMR spectrum (Table 3 ) displayed a total of 16 carbon resonances, including three typical oxygen-bearing carbons of 6a-hydroxypterocarpan at $\delta_{\mathrm{c}} 70.2$ (t, C-6), 78.7 (s, C-6a) and 91.4 (d, C-11a). Three olefinic protons at $\delta_{\mathrm{H}} 6.80(\mathrm{~d}, J=10.0 \mathrm{~Hz}, \mathrm{H}-1), 6.09(\mathrm{dd}$, $J=10.0,1.8 \mathrm{~Hz}, \mathrm{H}-2)$, and 5.41 (d, $J=1.8 \mathrm{~Hz}, \mathrm{H}-4)$ were assignable to A-ring by comparison with hydroxycristacarpone (15) (Fig. 1) [18], and their spectral difference was almost completely rooted in the $\mathrm{D}$ ring. Two aromatic singlets at $\delta_{\mathrm{H}} 6.81(\mathrm{~s}, \mathrm{H}-7), 6.26(\mathrm{~s}, \mathrm{H}-10)$ and a methylenedioxy signal at $\delta_{\mathrm{H}} 5.90,5.89$ (each $1 \mathrm{H}, \mathrm{d}$, $J=1.0 \mathrm{~Hz}$ ) were newly detected, while the prenyl and methoxy signals disappeared, which suggested that the methylenedioxy group should be connected to C-8 and C-9. The inference was confirmed by the HMBC correlations from the proton at $\delta_{\mathrm{H}} 6.81(\mathrm{~s}, \mathrm{H}-7)$ to the carbons at $\delta_{\mathrm{c}} 78.7$ (s, C-6a), 144.2 (s, C-8), and 151.6 (s, C-9), and from the methylenedioxy protons to the carbons at $\delta_{\mathrm{c}} 144.2$ (s, C-8), and 151.6 (s, C-9). Regrettably, it was inconclusive to establish relative configurations at C-6a, C-11a and C-11b by ROESY analysis, since the pivotal hydroxy signals were undetectable in $\mathrm{CD}_{3} \mathrm{OD}$. As we know, hydroxy proton signals were observable and often appeared as sharp peaks in DMSO- $d_{6}$, and their HMBC and ROESY correlations often played an important role in structure elucidation, especially the determination of relative configuration [19].

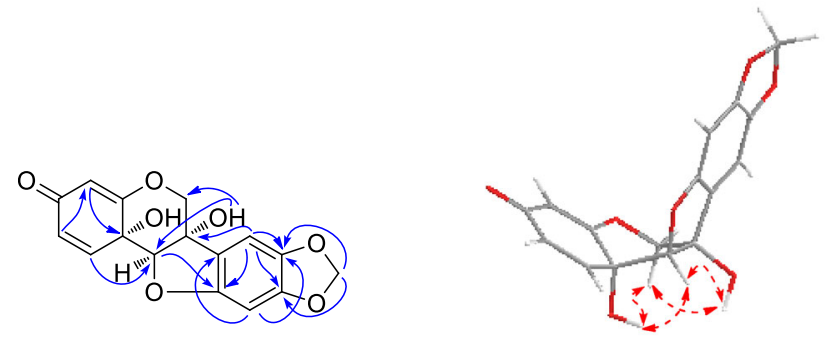

Fig. 2 Key HMBC $(\multimap)$ and ROESY $\left(\bullet^{-}\right)$correlations of pterocarpadiol A (1)
The clear ROESY correlation (DMSO- $d_{6}$, Fig. 2) of $6 a-O H$ $\leftrightarrow \mathrm{H}-11 \mathrm{a}$ revealed a cis fusion of the $\mathrm{B} / \mathrm{C}$ ring junction, while the correlations of $11 \mathrm{~b}-\mathrm{OH} \leftrightarrow \mathrm{H}-11 \mathrm{a}$ and $\mathrm{H}-6 \alpha$ indicated $\alpha$-orientation of the hydroxy group at $\mathrm{C}-11 \mathrm{~b}$. Accordingly, the structure of $\mathbf{1}$ was established and named as pterocarpadiol A.

Compound 2, white amorphous powder, had a molecular formula of $\mathrm{C}_{16} \mathrm{H}_{14} \mathrm{O}_{6}$ based on the positive-ion HRESIMS at $m / z \quad 325.0674[\mathrm{M}+\mathrm{Na}]^{+}$(calcd for $\mathrm{C}_{16} \mathrm{H}_{14} \mathrm{O}_{6} \mathrm{Na}$, 325.0683). The NMR spectroscopic data (Tables 1, 3) were similar to those of pterocarpadiol A (1), and the major difference was that its NMR spectra newly displayed a methoxy group $\left(\delta_{\mathrm{H}} 3.72 ; \delta_{\mathrm{c}}\right.$ 56.0) instead of the methylenedioxy. And then three aromatic protons at $\delta_{\mathrm{H}}$ 7.25 (d, $J=8.5 \mathrm{~Hz}, \mathrm{H}-7), 6.55$ (dd, $J=8.5,2.4 \mathrm{~Hz}, \mathrm{H}-8$ ), and $6.29(\mathrm{~d}, J=2.4 \mathrm{~Hz}, \mathrm{H}-10)$ were assignable to an ABX-type aromatic D-ring. The methoxy group was linked to $\mathrm{C}-9$ on the basis of the HMBC correlations from the proton at $\delta_{\mathrm{H}} 7.25(\mathrm{~d}, J=8.5 \mathrm{~Hz}, \mathrm{H}-7)$ to the carbons at $\delta_{\mathrm{c}}$ 78.0 (s, C-6a), 164.2 (s, C-9), and 162.9 (s, C-10a), and from the methoxy protons at $\delta_{\mathrm{H}} 3.72$ (s) to the carbon at $\delta_{\mathrm{c}}$ 164.2 (s, C-9). Therefore, the structure of 2 was established and named as pterocarpadiol $\mathrm{B}$.

Compound 3, white amorphous powder, possessed a molecular formula of $\mathrm{C}_{16} \mathrm{H}_{14} \mathrm{O}_{7}$ according to its positiveion HRESIMS at $\mathrm{m} / z \quad 341.0620[\mathrm{M}+\mathrm{Na}]^{+}$(calcd for $\mathrm{C}_{16} \mathrm{H}_{14} \mathrm{O}_{7} \mathrm{Na}$, 341.0632), which was 2 m.u. higher than that of 1. Signals of an oxymethylene at $\delta_{\mathrm{H}} 4.49,4.28$ (each $1 \mathrm{H}$, $\mathrm{d}, J=10.0 \mathrm{~Hz}, \mathrm{H}-6)$, an oxymethine at $\delta_{\mathrm{H}} 4.44$ (s, H-11a), an olefinic proton at $\delta_{\mathrm{H}} 5.22(\mathrm{~s}, \mathrm{H}-4)$, two aromatic singlets at $6.93(\mathrm{~s}, \mathrm{H}-7), 6.49(\mathrm{~s}, \mathrm{H}-10)$ and a methylenedioxy at $\delta_{\mathrm{H}}$ 5.96, 5.94 (each $1 \mathrm{H}, \mathrm{s}$ ) were observed in the ${ }^{1} \mathrm{H}$ NMR spectrum (Table 2). By comparison of the NMR spectra

Table $2{ }^{1} \mathrm{H}$ NMR spectroscopic data for pterocarpadiol A (1) and pterocarpadiol C (3) in DMSO- $d_{6}\left(\delta_{\mathrm{H}} 2.49 \mathrm{ppm}\right)$

\begin{tabular}{lll}
\hline No. & $\mathbf{1}$ & $\mathbf{3}$ \\
\hline 1 & $6.79(\mathrm{~d}, 10.0)$ & $2.43(\mathrm{td}, 14.1,4.5, \mathrm{H} \beta)$ \\
& & $1.93(\mathrm{ddd}, 14.1,4.9,2.8, \mathrm{H} \alpha)$ \\
2 & $6.02(\mathrm{dd}, 10.0,1.3)$ & $2.65(\mathrm{ddd}, 16.0,14.1,4.9, \mathrm{H} \alpha)$ \\
& & $2.16(\mathrm{ddd}, 16.0,4.5,2.8, \mathrm{H} \beta)$ \\
4 & $5.32(\mathrm{~d}, 1.3)$ & $5.22(\mathrm{~s})$ \\
6 & $4.79(\mathrm{~d}, 10.1, \mathrm{H} \alpha)$ & $4.49(\mathrm{~d}, 10.0, \mathrm{H} \alpha)$ \\
& $4.36(\mathrm{~d}, 10.1, \mathrm{H} \beta)$ & $4.28(\mathrm{~d}, 10.0, \mathrm{H} \beta)$ \\
7 & $6.93(\mathrm{~s})$ & $6.93(\mathrm{~s})$ \\
10 & $6.44(\mathrm{~s})$ & $6.49(\mathrm{~s})$ \\
$11 \mathrm{a}$ & $4.68(\mathrm{~s})$ & $4.44(\mathrm{~s})$ \\
OCH ${ }_{2} \mathrm{O}$ & $5.94(\mathrm{~s})$ & $5.96(\mathrm{~s})$ \\
& $5.93(\mathrm{~s})$ & $5.94(\mathrm{~s})$ \\
OH-6a & $6.40(\mathrm{~s})$ & $6.31(\mathrm{~s})$ \\
OH-11b & $6.77(\mathrm{~s})$ & $6.27(\mathrm{~s})$ \\
\hline
\end{tabular}


Table $3{ }^{13} \mathrm{C}$ NMR spectroscopic data for pterocarpadiols A-D (1-4)

\begin{tabular}{lrrrrrr}
\hline No. & \multicolumn{1}{c}{$\mathbf{1}^{\mathrm{a}}$} & \multicolumn{1}{c}{$\mathbf{2}^{\mathrm{a}}$} & \multicolumn{1}{c}{$\mathbf{3}^{\mathrm{a}}$} & \multicolumn{1}{l}{$\mathbf{4}^{\mathrm{a}}$} & \multicolumn{1}{l}{$\mathbf{1}^{\mathrm{b}}$} & \multicolumn{1}{c}{$\mathbf{3}^{\mathrm{b}}$} \\
\hline 1 & $146.5 \mathrm{~d}$ & $146.5 \mathrm{~d}$ & $32.7 \mathrm{t}$ & $32.8 \mathrm{t}$ & $144.9 \mathrm{~d}$ & $31.2 \mathrm{t}$ \\
2 & $128.9 \mathrm{~d}$ & $128.9 \mathrm{~d}$ & $32.8 \mathrm{t}$ & $32.8 \mathrm{t}$ & $127.8 \mathrm{~d}$ & $31.8 \mathrm{t}$ \\
3 & $190.2 \mathrm{~s}$ & $190.2 \mathrm{~s}$ & $202.1 \mathrm{~s}$ & $202.1 \mathrm{~s}$ & $187.0 \mathrm{~s}$ & $197.7 \mathrm{~s}$ \\
4 & $106.9 \mathrm{~d}$ & $106.9 \mathrm{~d}$ & $108.9 \mathrm{~d}$ & $108.9 \mathrm{~d}$ & $105.8 \mathrm{~d}$ & $107.5 \mathrm{~d}$ \\
$4 \mathrm{a}$ & $172.9 \mathrm{~s}$ & $172.9 \mathrm{~s}$ & $174.2 \mathrm{~s}$ & $174.1 \mathrm{~s}$ & $169.8 \mathrm{~s}$ & $170.9 \mathrm{~s}$ \\
6 & $70.2 \mathrm{t}$ & $70.4 \mathrm{t}$ & $70.5 \mathrm{t}$ & $70.8 \mathrm{t}$ & $68.7 \mathrm{t}$ & $68.9 \mathrm{t}$ \\
$6 \mathrm{a}$ & $78.7 \mathrm{~s}$ & $78.0 \mathrm{~s}$ & $78.8 \mathrm{~s}$ & $78.1 \mathrm{~s}$ & $76.9 \mathrm{~s}$ & $76.9 \mathrm{~s}$ \\
$6 \mathrm{~b}$ & $119.9 \mathrm{~s}$ & $120.9 \mathrm{~s}$ & $121.0 \mathrm{~s}$ & $122.1 \mathrm{~s}$ & $119.7 \mathrm{~s}$ & $120.6 \mathrm{~s}$ \\
7 & $104.1 \mathrm{~d}$ & $125.6 \mathrm{~d}$ & $104.1 \mathrm{~d}$ & $125.5 \mathrm{~d}$ & $103.9 \mathrm{~d}$ & $103.8 \mathrm{~d}$ \\
8 & $144.2 \mathrm{~s}$ & $109.5 \mathrm{~d}$ & $144.2 \mathrm{~s}$ & $109.4 \mathrm{~d}$ & $142.1 \mathrm{~s}$ & $142.0 \mathrm{~s}$ \\
9 & $151.6 \mathrm{~s}$ & $164.2 \mathrm{~s}$ & $151.4 \mathrm{~s}$ & $164.1 \mathrm{~s}$ & $149.4 \mathrm{~s}$ & $149.1 \mathrm{~s}$ \\
10 & $93.6 \mathrm{~d}$ & $96.4 \mathrm{~d}$ & $93.6 \mathrm{~d}$ & $96.6 \mathrm{~d}$ & $92.7 \mathrm{~d}$ & $92.6 \mathrm{~d}$ \\
$10 \mathrm{a}$ & $156.5 \mathrm{~s}$ & $162.9 \mathrm{~s}$ & $155.8 \mathrm{~s}$ & $162.2 \mathrm{~s}$ & $154.5 \mathrm{~s}$ & $153.7 \mathrm{~s}$ \\
$11 \mathrm{a}$ & $91.4 \mathrm{~d}$ & $91.4 \mathrm{~d}$ & $91.8 \mathrm{~d}$ & $91.8 \mathrm{~d}$ & $89.6 \mathrm{~d}$ & $89.9 \mathrm{~d}$ \\
$11 \mathrm{~b}$ & $68.8 \mathrm{~s}$ & $68.8 \mathrm{~s}$ & $69.7 \mathrm{~s}$ & $69.7 \mathrm{~s}$ & $67.1 \mathrm{~s}$ & $67.9 \mathrm{~s}$ \\
$\mathrm{OCH}_{2} \mathrm{O}$ & $103.0 \mathrm{t}$ & & $102.9 \mathrm{t}$ & & $101.6 \mathrm{t}$ & $101.4 \mathrm{t}$ \\
$\mathrm{OCH}_{3}$ & & $56.0 \mathrm{q}$ & & $56.0 \mathrm{q}$ & & \\
\hline
\end{tabular}

${ }^{\text {a }}$ Measured in $\mathrm{CD}_{3} \mathrm{OD}\left(\delta_{\mathrm{c}} 49.0 \mathrm{ppm}\right)$

b Measured in DMSO- $d_{6}\left(\delta_{\mathrm{c}} 39.5 \mathrm{ppm}\right)$

(Tables 2, 3) of $\mathbf{3}$ and 1, two ortho-coupled doublets and the corresponding olefinic carbons were absent whereas two $s p^{3}$ carbons at $\delta_{\mathrm{c}} 31.2(\mathrm{t})$ and $\delta_{\mathrm{c}} 31.8(\mathrm{t})$ were newly detected, which hinted that 3 should be 1,2-dihydropterocarpadiol A. The inference was confirmed by the HMBC correlations from the proton at $\delta_{\mathrm{H}} 2.43(\mathrm{td}, 14.1,4.5, \mathrm{H}-1 \beta)$ to the carbon at $\delta_{\mathrm{c}} 89.9(\mathrm{~d}, \mathrm{C}-11 \mathrm{a})$ and from the proton at $\delta_{\mathrm{H}} 2.16(\mathrm{ddd}, 16.0,4.5,2.8, \mathrm{H}-2 \beta)$ to the carbon at $\delta_{\mathrm{c}} 107.5$ (d, C-4). The clear ROESY correlations (DMSO- $d_{6}$ ) of $6 \mathrm{a}-$ $\mathrm{OH} / 11 \mathrm{~b}-\mathrm{OH} \leftrightarrow \mathrm{H}-11 \mathrm{a}$ indicated that 3 possessed the same stereochemistry as $\mathbf{1}$. Thus, the structure of $\mathbf{3}$ was established and named as pterocarpadiol $\mathrm{C}$.

Compound $\mathbf{4}$, white amorphous powder, had a molecular formula of $\mathrm{C}_{16} \mathrm{H}_{16} \mathrm{O}_{6}$ determined by the positive-ion HRESIMS at $\mathrm{m} / \mathrm{z} \quad 327.0819 \quad[\mathrm{M}+\mathrm{Na}]^{+}$(calcd for $\mathrm{C}_{16} \mathrm{H}_{16} \mathrm{O}_{6} \mathrm{Na}$, 327.0839). The NMR spectroscopic data

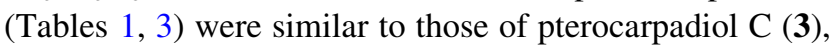
and the obvious difference was that a methoxy signal $\left(\delta_{\mathrm{H}}\right.$ $3.74 ; \delta_{\mathrm{c}} 56.0$ ) replaced the methylenedioxy in $\mathbf{3}$. According to the HMBC correlations from the proton at $\delta_{\mathrm{H}} 7.25(\mathrm{~d}$, $J=8.0 \mathrm{~Hz}, \mathrm{H}-7$ ) to the carbons at $\delta_{\mathrm{c}} 78.1$ (s, C-6a), 164.1 (s, C-9), and 162.2 (s, C-10a), and from the methoxy protons at $\delta_{\mathrm{H}} 3.74$ (s) to the carbon at $\delta_{\mathrm{c}} 164.1$ (s, C-9), the methoxy group was positioned at $\mathrm{C}-9$ as with the previous structure. Thus, the structure of $\mathbf{4}$ was established and named as pterocarpadiol D.

Pterocarpans isolated in our current research such as pisatin (7), variabilin (8), and maackiain (11) exhibited without exception negative optical rotation values $\left(-286^{\circ}\right.$, $-304^{\circ}$, and $-260^{\circ}$, respectively), and their absolute configurations had been established as $6 \mathrm{a} S, 11 \mathrm{aS}$ (7), $6 \mathrm{a} S, 11 \mathrm{a} S(\mathbf{8})$, and $6 \mathrm{a} R, 11 \mathrm{a} R$ (11) [20]. As their related coconstituents, pterocarpadiols A-D (1-4) also gave large negative optical rotation values $\left(-484.0^{\circ},-397.0^{\circ}\right.$, $-507.0^{\circ}$ and $-476.0^{\circ}$, respectively), thereupon we assumed that the absolute configurations of 1-4 could be assigned as $6 \mathrm{a} S, 11 \mathrm{a} R, 11 \mathrm{~b} S$ depicted in Fig. 1. Nonetheless, this issue deserved further studies in the future. Until now, only two 6a,11b-dihydroxypterocarpans: hydroxytuberosone [21] and hydroxycristacarpone [18], were reported and only from the family Leguminosae, therefore pterocarpadiols A-D as chemical markers in Derris species may be helpful in chemotaxonomical classification.

\section{Experimental Section}

\subsection{General Experimental Procedures}

Optical rotations were measured on a Jasco P-1020 automatic digital polarimeter. UV data were obtained from HPLC online analysis. NMR spectra were carried out on a Bruker AV-400, Bruker DRX-500 or Bruker AV-800 spectrometer with deuterated solvent signals used as internal standards. ESI and HRESIMS were performed with a Shimadzu LC-IT-TOF mass spectrometer equipped with an ESI interface (Shimadzu, Kyoto, Japan). Silica gel 200-300 mesh (Qingdao Marine Chemical Inc., Qingdao, China), Chromatorex C-18 $(40-75 \mu \mathrm{m}$, Fuji Silysia Chemical Ltd., Japan) and Sephadex LH-20 (Amersham Biosciences, Uppsala, Sweden) were used for normal pressure column chromatography (CC). Fractions were monitored and analyzed by TLC, in combination with Agilent 1200 series HPLC system equipped by Extend-C18 column $(5 \mu \mathrm{m}, 4.6 \times 150 \mathrm{~mm})$.

\subsection{Plant Material}

The twigs and leaves of D. robusta were collected from the Pu'er region of Yunnan Province, China, in May 2011, and identified by Mr. Yu Chen of Kunming Institute of Botany. A voucher specimen (BBP0350021DR) was deposited at BioBioPha Co., Ltd.

\subsection{Extraction and Isolation}

The air-dried and powdered twigs and leaves $(12.0 \mathrm{~kg})$ of D. robusta were extracted with $95 \% \mathrm{EtOH}$ at room temperature, and the solvent was removed under reduced pressure to give crude extract (ca. $870 \mathrm{~g}$ ), which was fractionated by silica gel CC successively eluted with petroleum ether (PE)/acetone gradient and then $\mathrm{MeOH}$ to 
yield nine fractions A-I. Fraction $\mathrm{C}$ (PE/acetone, 6:1) was subjected to silica gel $\mathrm{CC}\left(\mathrm{CHCl}_{3} / \mathrm{MeOH}, 100: 0 \rightarrow 100: 2\right)$ and Sephadex LH-20 $\left(\mathrm{CHCl}_{3} / \mathrm{MeOH}, 1: 1 ;\right.$ or $\left.\mathrm{MeOH}\right)$ to give $5(51 \mathrm{mg}), \mathbf{6}(185 \mathrm{mg}), \mathbf{7}(138 \mathrm{mg}), \mathbf{8}(262 \mathrm{mg}), \mathbf{1 1}$ $(665 \mathrm{mg})$, and $12(608 \mathrm{mg})$, and the remainder was separated by RP-18 $\left(40 \% \mathrm{MeOH} / \mathrm{H}_{2} \mathrm{O}\right)$ and Sephadex LH-20 $(\mathrm{MeOH})$ to yielded $9(661 \mathrm{mg})$ and $\mathbf{1 0}(349 \mathrm{mg})$. The fraction $\mathrm{E}$ (PE/acetone, 4:1) was repeatedly applied to silica gel $\mathrm{CC}\left(\mathrm{CHCl}_{3} / \mathrm{MeOH}, 30: 1 \rightarrow 15: 1\right)$ and Sephadex LH-20 (MeOH) to yiele $\mathbf{1 3}(23 \mathrm{mg})$ and $\mathbf{1 4}(114 \mathrm{mg})$. The fraction $\mathrm{F}$ (PE/acetone, 3:1) was repeatedly separated on silica gel $\mathrm{CC}\left(\mathrm{CHCl}_{3} / \mathrm{MeOH}, 10: 1\right)$, Sephadex LH-20 $\left(\mathrm{CHCl}_{3} / \mathrm{MeOH}, 1: 1\right)$ and $\mathrm{RP}-18\left(40 \% \mathrm{MeOH} / \mathrm{H}_{2} \mathrm{O}\right)$ to yield $\mathbf{1}(233 \mathrm{mg})$ and $\mathbf{2}(33 \mathrm{mg})$, and the remainder was further isolated on silica gel $\left(\mathrm{CHCl}_{3} / \mathrm{MeOH}, 10: 1\right)$, Sephadex LH-20 (MeOH) and RP-18 $\left(45 \% \mathrm{MeOH} / \mathrm{H}_{2} \mathrm{O}\right)$ to yield $3(47 \mathrm{mg})$ and $4(28 \mathrm{mg})$. The retention times $\left(t_{\mathrm{R}}\right)$ of 1-4 on an analytical HPLC Extend-C18 column $\left(20 \% \rightarrow 100 \% \mathrm{MeOH}\right.$ in $\mathrm{H}_{2} \mathrm{O}$ over 8.0 min followed by $100 \% \mathrm{MeOH}$ to $13.0 \mathrm{~min}, 1.0 \mathrm{ml} / \mathrm{min}, 25^{\circ} \mathrm{C}$ ) were 6.03 , $6.16,6.50$, and $6.60 \mathrm{~min}$, respectively.

\subsection{Pterocarpadiol A (1)}

White amorphous powder; UV $(\mathrm{MeOH}) \lambda_{\text {max }}: 235$, $306 \mathrm{~nm} ;[\alpha]_{\mathrm{D}}^{23}-484.0(c 0.5, \mathrm{MeOH}) ;{ }^{1} \mathrm{H}$ NMR data: see Tables 1 and 2; ${ }^{13} \mathrm{C}$ NMR data: see Table 3; ESIMS (pos.): $\mathrm{m} / z \quad 339 \quad[\mathrm{M}+\mathrm{Na}]^{+}$; HRESIMS (pos.): $\mathrm{m} / \mathrm{z} 339.0462$ $[\mathrm{M}+\mathrm{Na}]^{+}$(calcd for $\mathrm{C}_{16} \mathrm{H}_{12} \mathrm{O}_{7} \mathrm{Na}, 339.0475$ ).

\subsection{Pterocarpadiol B (2)}

White amorphous powder; UV $(\mathrm{MeOH}) \lambda_{\max }: 230,285$, $305 \mathrm{~nm} ;[\alpha]_{\mathrm{D}}^{22}-397.0($ c $0.2, \mathrm{MeOH}) ;{ }^{1} \mathrm{H}$ NMR data: see Table 1; ${ }^{13} \mathrm{C}$ NMR data: see Table 3; ESIMS (pos.): $\mathrm{m} / \mathrm{z}$ $325[\mathrm{M}+\mathrm{Na}]^{+}$; HRESIMS (pos.): $\mathrm{m} / \mathrm{z} 325.0674[\mathrm{M}+\mathrm{Na}]^{+}$ (calcd for $\mathrm{C}_{16} \mathrm{H}_{14} \mathrm{O}_{6} \mathrm{Na}, 325.0683$ ).

\subsection{Pterocarpadiol C (3)}

White amorphous powder, UV $(\mathrm{MeOH}) \lambda_{\max }: 260$, $308 \mathrm{~nm} ;[\alpha]_{\mathrm{D}}^{23}-507.0($ c $0.2, \mathrm{MeOH}) ;{ }^{1} \mathrm{H}$ NMR data: see Tables 1 and 2; ${ }^{13} \mathrm{C}$ NMR data: see Table 3; ESIMS (pos.): $\mathrm{m} / \mathrm{z} 341 \quad[\mathrm{M}+\mathrm{Na}]^{+}$; HRESIMS (pos.): $\mathrm{m} / \mathrm{z}, 341.0620$ $[\mathrm{M}+\mathrm{Na}]^{+}$(calcd for $\mathrm{C}_{16} \mathrm{H}_{14} \mathrm{O}_{7} \mathrm{Na}, 341.0632$ ).

\subsection{Pterocarpadiol D (4)}

White amorphous powder, UV $(\mathrm{MeOH}) \lambda_{\max }: 232$, $261 \mathrm{~nm} ;[\alpha]_{\mathrm{D}}^{23}-476.0($ c $0.2, \mathrm{MeOH}) ;{ }^{1} \mathrm{H}$ NMR data: see Table 1; ${ }^{13} \mathrm{C}$ NMR data: see Table 3; ESIMS (pos.): $\mathrm{m} / \mathrm{z}$
$327[\mathrm{M}+\mathrm{Na}]^{+}$; HRESIMS (pos.): $\mathrm{m} / z 327.0819[\mathrm{M}+\mathrm{Na}]^{+}$ (calcd for $\mathrm{C}_{16} \mathrm{H}_{16} \mathrm{O}_{6} \mathrm{Na}, 327.0839$ ).

Acknowledgments This work was financially supported by the "Large-scale Compound Library" project of National Development and Reform Commission of China.

\section{Compliance with Ethical Standards}

Conflict of Interest The authors declare no conflict of interest.

Open Access This article is distributed under the terms of the Creative Commons Attribution 4.0 International License (http:// creativecommons.org/licenses/by/4.0/), which permits unrestricted use, distribution, and reproduction in any medium, provided you give appropriate credit to the original author(s) and the source, provide a link to the Creative Commons license, and indicate if changes were made.

\section{References}

1. Editorial Committee of Flora Reipublicae Popularis Sinicae, Flora Reipublicae Popularis Sinicae. Academic Press: Beijing 40, 194-195 (1994)

2. X.Y. Yang, R.J. Ma, L.Q. Wang, T. Li, Nat. Prod. Res. Dev. 25, 117-128 (2013)

3. F. Wang, Y. Gao, L. Zhang, J.K. Liu, Org. Lett. 12, 2354-2357 (2010)

4. F. Wang, Y.J. Li, F.C. Ren, G.Z. Wei, J.K. Liu, Chem. Pharm. Bull. 59, 484-487 (2011)

5. Y. Gao, G.Q. Wang, K. Wei, P. Hai, F. Wang, J.K. Liu, Org. Lett. 14, 5936-5939 (2012)

6. F. Wang, X.L. Li, G.Z. Wei, F.C. Ren, J.K. Liu, Nat. Prod. Bioprospect. 3, 238-242 (2013)

7. P. Hai, S.Z. Wen, Y. Li, Y. Gao, X.J. Jiang, F. Wang, Nat. Prod. Bioprospect. 4, 47-51 (2014)

8. A.F. Barrero, E. Cabrera, I.R. Garcia, Phytochemistry 48, 187-190 (1998)

9. M.F. Hegazy, A.E.H. Mohamed, A.M. El-Halawany, P.C. Djemgou, A.A. Shahat, P.W. Paré, J. Nat. Prod. 74, 937-942 (2011)

10. T.G. van Aardt, H. van Rensburg, D. Ferreira, Tetrahedron 57, 7113-7126 (2001)

11. A. Fuchs, F.W.D. Vries, C.A. Landheer, A.V. Veldhuizen, Phytochemistry 19, 917-919 (1980)

12. F.A. Macías, A.M. Simonet, J.C.G. Galindo, D. Castellano, Phytochemistry 50, 35-46 (1999)

13. T. Kinoshita, K. Ichinose, C. Takahashi, F.C. Ho, J.B. Wu, U. Sankawa, Chem. Pharm. Bull. 38, 2756-2759 (1990)

14. J.F. Zeng, D.Y. Zhu, Acta Bot. Sin. 41, 997-1001 (1999)

15. E. Malan, E. Swinny, Phytochemistry 29, 3307-3309 (1990)

16. T. Miyase, A. Ueno, T. Noro, S. Fukushima, Chem. Pharm. Bull. 28, 1172-1177 (1980)

17. H. Tanaka, T. Tanaka, H. Etoh, Phytochemistry 45, 205-207 (1997)

18. H. Tanaka, T. Tanaka, H. Etoh, Phytochemistry 42, 1473-1475 (1996)

19. F. Wang, D.S. Zhou, G.Z. Wei, F.C. Ren, J.K. Liu, Phytochemistry 77, 312-317 (2012)

20. J.L. Ingham, K.R. Markham, Phytochemistry 19, 1203-1207 (1980)

21. A.V.K. Prasad, A. Singh, R.S. Kapil, S.P. Popli, Indian J. Chem. 23B, 1165-1167 (1984) 